\title{
Antibiotic Susceptibilities and SDS-PAGE Protein Profiles of Methicillin-Resistant Staphylococcus Aureus (MRSA) Strains Obtained from Denizli Hospital
}

\author{
Göksel Doğan, Gülümser Acar Doğanlı, \\ Yasemin Gürsoy and Nazime Mercan Doğan \\ Additional information is available at the end of the chapter \\ http://dx.doi.org/10.5772/55457
}

\section{Introduction}

Soon after two years of introducing methicillin, S. aureus strains developed resistance to methicillin by through the gain of the mecA gene (MRSA). At first S. aureus strains were exclusively related to hospital acquired (HA) MRSA, but as from 1990s, community acquired (CA) MRSA came into view [1].

In both HA-MRSAs and CA- MRSAs are refered to as a significant factor of serious infections in high morbidity and mortality including bacteremia, pneumonia, endocarditis, osteomyelitis and toxic shock syndrome $[2,3,4,5,6]$. The factors that increase the prevalence of nosocomial bacteremia are the increase in older age groups in society, life period prolongation of people with chronic diseases, widespread use of immunosuppressive drugs, increase in interventional procedures for the purposes of diagnostic and therapeutic. Generally, some of staphylococ infections are nasocomial, other infections have occured by depending on MRSAs. The colonization rate with MRSA has increased in parallel duration of hospitalization. These strains have been found resistant against penicillins, combinations of betalactam/betalactamase inhibitory, sephalosporins, combinations of monobactames and carpenemes. To identify the resistance of staphylococcus's against methycillin antibiotic, those methods as of disc diffusion, tube dilution or microdilution, agar scanning, agar dilution, automatise susceptibility tests, DNA hybridisation technics and polimeraze chain reaction have been used [7,8,9]. The aim of this study is to identify antibiotic susceptibility and specificity of MRSAs isolated from various clinic samples with various methods including disc diffusion, SDS-PAGE and DNase test. 


\section{Methicillin resistant Staphylococcus aureus}

\subsection{General properties}

S. aureus (including MRSA strains) are clusterforming, facultative aerobic, Gram-positive cocci (at 0.5-1.7 $\mu$ of diameters) with intrinsic ability to ferment carbohydrates, producing white to deep yellow pigmentation on solid culture media [2].

$50 \%$ of cell wall of Staphylococci has composed from peptidoglycan. Peptidoglycan chains consist of alternative polysaccharide subunits included $\mathrm{N}$-acetyl glucosamines and $\mathrm{N}$-acetyl muramik acid. These chains are cross linkage by pentaglycine bridges that are specific for S.aureus and tetra peptide chains binded with $\mathrm{N}$ - acetyl muramik acid. Peptidoglycan can show endotoxin properties and structural differences among strains can lead to extensive intravenous coagulation $[10,11]$.

Most researchers demonstrated that MRSAs caused various diseases ranging from soft, superficial dermatological diseases to acute and potentially fatal systemic enervations $[2,12,13]$. Some MRSAs live as a normal flora member in human mucose membrans and skins, others lead to ichor, abscess formation, various piogen infections and fatal septicemia. MRSA strains have also been detected in domestic animals and birds such as horses, cattle, chickens and dogs as well as associated individuals [2].

Staphylococcus aureus is coagulase positive and major patogen for humans. In general pathologic Staphylocci hemolysis the blood, coagulates the plasma, and also produces various extracellular enzymes and toxins. They have developed quickly against antimicrobial drugs [14].

\subsection{Culture properties}

Staphylococci grows easily aerobic or microaerofilic conditions. Optimal temperature is $37^{\circ} \mathrm{C}$ for these bacteria. Colonies of them are orbicular, sleek, bouffant and brilliant in solid media. In general, S.aureus has colonie colours that change from white to golden yellow. However, in many colonies, pigment occurs by those bacteria after long incubation time. It does not occur under anaerobic conditions or in broth [14].

\subsection{Growing properties}

Staphylococci have produced catalase variously then Streptococci. Staphylococci fermentate carbohydrates slowly by constituting acid, but they do not produce gases. On the other hand, pathogenic Staphylococci have generated so many extracellular substances. Even though, Staphylococci are durable against conditions of dry air, temperature $\left(50^{\circ} \mathrm{C}, 30 \mathrm{~m}\right)$ and $9 \%$ of $\mathrm{NaCI}$, but they can be inactivated easly with powerful chemicals such as $3 \%$ of hexaclorofen. Other one theme, these bacteria are sensetive against many of antimicrobial drugs. Resistant separates several of categories;

Mechanism of methicillin resistant: The resistant agaist beta-lactame antibiotics (methicillin, oxacillin, nafcillin, kloxacillin and dikloxacillin) not having been hyrolysed with beta-lacta- 
mase enzyme has denominated as methicillin resistant. Thus, it is clear that the resitant is chromosomal and is not with beta-lactamase enzyme inactivated the antibiotic $[15,16]$.

PBP 2a (PBP 2'): Alhough methicillin sensitive S. Aureus (MSSA) has five types of penicillin binding proteins (PBP), in addition these proteins, methicillin resistant $S$. Aureus (MRSA) has also a different penicillin binding protein named as PBP 2' or PBP 2a. This protein has $78 \mathrm{kDa}$ of molecular weight [17]. PBP 2a shows lower affinity against beta-lactame antibiotics then other PBPs. Hence, the enzyme is single trancepeptidase that has the ability to continue of peptidoglycan synthesis by showing high affinity in presence of beta-lactame antibiotics $[13,18]$. The gene encoded PBP 2a is $2.1 \mathrm{~kb}$ and named mecA. Though, all of MRSAs have this gene, but there is no this gene at MSSA strains. The emergence of methicillin resistant phenotypeclly has been able to show variability among bacteria. The phenotypically expiration of methicillin resistant is possible in two ways; homogen and heterogen [17]. In homogen resistant, all of cells show high levels of resistance in presence of high methicillin consentrations by growing $[19,11]$. In hetrogen resistance, even though all cells have mec $A$ gene had information that needs for methicillin resitance, only some cells show resistance.

a. mecR1-mecI sistemi: The mecA have been controled with two regulator genes. Those genes are $m e c R 1$ and mecI. Also these genes are similar to blaR 1 and blaI, which are regulatory genes of beta-lactamase, in terms of structure, fonction and mechanism of regulation. MecI and $m e c R 1$ have the same regulator role for mecA. MecR 1 encodes a signal stimulant protein, while mecl encodes a protin suppressed the mec $A[15,16]$

b. Other factors affected resistant phenotype:

- Beta-lactamase plasmid: Production of beta-lactamase enzyme is encoded by blaZ gene and is controled by genes of blaR1 and blaI which are antireceptor and receptor, recpectively. BlaR1 which is a transmembrane protein binds to beta-lactame in presence of it and leads to start the synthesyse of beta-lactamase enzyme by providing signal transmission from out of cell to inside of cell [20]. At the same time, it has been thought that genes of blaR1 and blaI have had a role for occuring of methicillin resistant phenotypically [17].

- Fem Factors: The obtaining sensitive strains from methicillin resistance strains by tranposones via inactivation had led to identification of genes beyond of mec. These genes placed out of mec gene region had defined as "auxiliary" or "factors essential for the expression of methicillin resistance" or shortly "fem" genes [21]. Both MRSA and MSSA strains have fem factors variously from mecA gene. Also, it indicated that some conditions increased the occuring of methicillin resistant were correlated with modifications at cell autolysis.

\subsection{Enzymes and toxins}

Staphylococci can lead to diseases by large diffusion at tissue and producing many extracellular substances. Some of these extracellular substances are enzymes, others are toxins. Most toxins are under genetic control of plasmids. Some of them can be under both kromosomal and ekstrakromosomal control [22,23,24,25]. 


\subsection{Coagulase and clumping factor}

S.aureus produces coagulase being an enzyme providing coagulation of the plasma. Coagulase that can be droped out freely binds the prothrombin and initiates polymerization of fibrin. It can also accumulate the fibrin at suface of Staphylocci. It thinks that products of coagulase are similar to invasive patogenic power.

Clumping Factor which is responsible for binding of organism to fibrin and fibrinogen-is a surface component of S.aureus. When clumbing factor comes up with plasma, S.aureus forms clumps. Clumping Factor is discret from coagulase [22,25].

\subsection{Enzymes}

Other enzymes produced by Staphylococcus's are sthapylokinase, proteinase, DNase and enzymes having different properties such as ß-lactamase.

\subsection{Exotoxins}

Alfa toxin is a heterogen protein acting by depending on large spectrum of eucariotic cell membrans. $\alpha$ toxin is a power hemolysin (a substance that causes the fragmentation of erytrosit). $\beta$ toxin have reduced the sphingomyelin, therefore it is toxic for many cells included human red blood cells. Additionally, an other toxin, $\delta$ is heterogen. It fractionates the biologic membrans and can have a role at diarrheal patients because of S.aureus.

\subsection{Leukocidin}

This toxin of S.aureus has two components. It affects white blood cells in humans and rabbits. These two components have moved synergistic like $\gamma$ toxin at the membrane of white blood cells. The toxin is an important virulance factor in community acquired MRSA (CA-MRSA) strains.

\subsection{Toxic shock syndrom toxin}

Many S.aureus strains isolated from patients with toxic shock syndrome produce the toxic shock syndrome toxin- 1 (TSST-1) also namely enterotoxin F. TSST- 1 is the super antigen and binds the MHC-II molecules that leads to T cell stimulation TSST-1. This toxin is related to febrile, shock and multisystem involvement which are scope skin disease.

\subsection{Diagnostic laboratory tests}

\subsubsection{Gram staining}

S. Aureus bacteria appears violet colour and looks like bunch of grapes by gram staining. It is imposible to separate pathogenic organism (S.aureus) from saprophytic organisms (S.epidermitis) by gram staining. 


\subsubsection{Catalase test}

MRSAs produce catalase, which converts hydrogen peroxide into water and oxygen. The catalase test differentiates the staphylococci from the streptococci [14].

\subsubsection{Susceptibility tests}

At choosing of advisable antibiotic drug associated with therapy of infection, a number of factors such as potential infectious agents, antibiotic susceptibility, host factors that may affect the activity of the drug in vivo, the location of the infection, pharmacokinetic and pharmacodynamic properties of the drug should be evaluate [26]. Generally, in vitro procedures applied for determination of antimicrobic activity of an antibiotic is named as susceptibility tests. Susceptibility tests apply in the cases of not foreseeable susceptibility against antibacterial agent which will be applied at treatment of aerob and facultative anaerob bacteria which are clinically important. Susceptibility against antimicrobic drugs can be detected with a lot of methods. In most, inhibitor activity of drugs (bacteriostatic) evaulates in applied method. The applied methods with this purpose can consider of; 1 . dilution methods in liquid and solid media; 2. disc diffusion method; 3. gradient diffusion (E-test) method; 4 . the detection of enzymes which inactivate antimicrobic agents [26].

At disc diffusion method, paper discs is absorbed a specific amount of antibiotic place onto plate inoculed with the test microorganism. Thus, antibiotic absorbed by disc diffuses into agar and inhibits the growing of bacteria at effect levels of antibiotic. At the end of this situation, a circular inhibition zone where does not grow bacteria occurs at ambient of the disc. The categories of susceptibility as of sensitive, medium and resistance identify by measuring diameter of this zone. The limit values related to these categories detect for every antimicrobic agent by regarding accescible serum levels [26,27]. For example, Staphilococci are mecA positive and are resistant against methicillin at Müller-Hinton agar contented 6 of $\mu \mathrm{g} / \mathrm{mL}$ of oxasilin and $4 \%$ of $\mathrm{NaCl}$.

\subsection{Community and hospital acquired MRSA infections}

Molecular epedemiology of community aquired MRSA (CA-MRSA) is tolerably different from hospital acquired MRSA (HA-MRSA). CA-infections commonly cause of skin and soft tisue infections, bacteremia and endocardit [2].

Panton-Valentine leukocidin (PVL) gene encoded a toxin which is responsible from virulance of bacteria and type $4 \mathrm{SCC}$ ec genetic component frequently are presence at CA-MRSA isolates $[22,16]$. HA-MRSA isolates generally have type I, II or III of staphylococcal casette chromosome (SCCmec) genetic component. This gene domain is responsible from showing resistant of bacteria against antibiotics made from beta-lactam and even other drugs such as clindamycin, gentamicin and florocinolon. Characterisation of the staphylococcal cassette chromosome (SCC) mec type has led to better discrimination of hospital acquired MRSA (HA-MRSA) and community acquired MRSA (CA-MRSA) [28]. SCCs are mobile elements characterized by association of a mec complex and ccr genes coding for integration into or excision from the chromosome. Three types of SCC (types I, II and III) were originally described in hospital- 
acquired MRSA strains (HA-MRSA), most of them isolated before 1990. A fourth type (type IV) was recently described, first in community-acquired MRSA isolates (CA-MRSA) and then in several MRSA backgrounds, including hospital isolates [29].

To compare HA-MRSA strains with CA-MRSA, It needs to examine several aspects. Innitially, chromosomal elements for meticillin resistance in community-associated strains are chromosome cassette mec (SCCmec) types IV or V, being smaller and more active than SCCmec types I-III found in hospital-acquired MRSA. In HA-MRSA, the larger gene elements are correlated with reduced bacterial ability as well as decreased toxin generation. Also, the PVL toxin is more common in CA-MRSA than in MSSA. Another thing, increased expression of certain virulence determinants which can cause more acute disease (e.g. phenol-soluble modulinsPSMs-) is available in CA MRSA. The last one,, while all S. aureus strains have an aptness to generate biofilms, it suggest that variations in biofilm matrix in CA-MRSA compared to other strains. But, there is no sufficient evidence in the literature that any of MRSA strain sample has a larger capability to cause invasive infection than MSSA strains [7].

\subsection{Clinic Infections}

\subsubsection{Skin and soft tisue infections}

CA-MRSA strains can be infected skin and soft tissue infections, which characteristically occur in healthy people without preconditions. For instance, the US had one of the biggest CA-MRSA epidemic, with one strain named USA300, being liable for most of infections. In 2005, $13.7 \%$ of all invasive MRSA infections in the US were community associated. [30]. Skin, soft tisue and bone infections seems at most. These infections can be confined from a localized infektion to more general infections such as cellulite, impedigo, folliculit, boll, carboncul and surgical wound infection. Staphylococcal bone marrow dermatitis (osteomyelitis) occurs typically at young children because of bacteremia. More severe manifestations can include necrotizing pneumonia, pyomyositis, sepsis, osteomyelitis and necrotizing fasciitis [7]. Even though, some of S.aureus infections corellate with development of TSS, nowadays most of patients have skin and soft tissue infections with this disease. For instance, Staphylococcal scalded skin syndrome seems at most in young children.It is less common in adults and older children. The reason is that some of toxins (exfoliative toxins; ETA and ETB) bind with GM4-like glycolipids in newborns sensitive epidermis. GM4-like glycolipids are not available in adult and children [31,32] Figure 1 shows a sample of skin and soft tisue infection of MRSA strains.

\subsection{Systemic infections}

\subsubsection{Pneumonia}

At 1918 in registries, obtained from influence pandemia of young individuals, most of deaths related with bacterial super infections that S.aureus strains lead to those infections. Recently, S.aureus isolates produced PVL toxin has relevanted to infections of skin and soft tisue such as pnömonia at healthy young people. PVL is a bi-component exotoxin transmitted by bacteriophages that is encoded by two genes, luk FPV and luk S-PV. PVL genes are carried by 


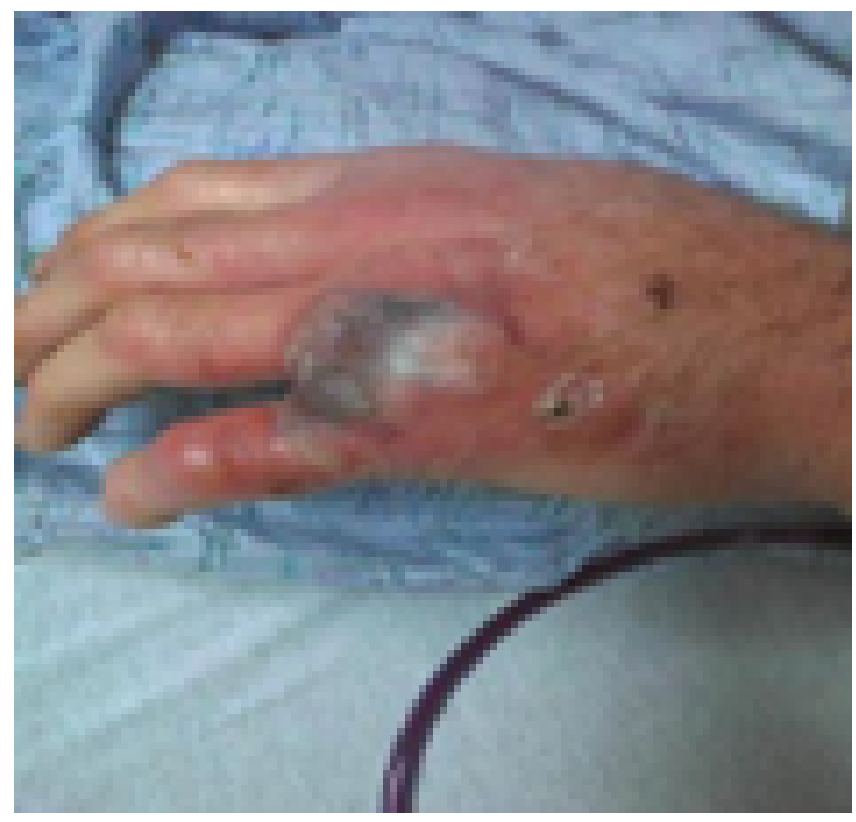

Figure 1. Skin and Soft tisue Infection of MRSA [33]

nearly every CA-MRSA strain as well as a small proportion of clinical MSSA strains. This suggests that PVL has an important role in fitness, transmissibility and virulence, but the role of PVL in the pathogenesis of CA-MRSA infections is controversial [7]. PVL is a toxin fragmented speedy the white blood cells. Also, these strains can be contained other virulance factors and toxins. Consequently, this kinf of infections have high rates of death.

\subsubsection{Treatment}

It is necessary the using of a penicillin which is resistant against $\beta$-lactamase in bacteremia, endocartidis, pneumonia and other infections which occur by S.aureus strains for long times. Vancomycin has been prefered at methicillin resistant strains. If the infections are because of S.aureus wich not produce $\beta$-lactamase, penicillin $\mathrm{G}$ has to choose for those infections. S.aureus strains izolated from clinic infections which are resistant against penicillin $\mathrm{G}$ always produce penicillinases. Those strains are generally sensitive against penicillins wich are resistant $\beta$ lactamases, cephalosporins or vancomycin. Resistant of methicillin is independent from producting of $\beta$-lactamase.

Resistant of drugs such as penicillin, tetracyclin, aminoglycosid and, erytromycin which has detected by plasmids can be transfered to other staphylococci by transduction and conjugation. Antibiotics such as linezolid, daptomycin and dalfopristin can be used at serious staphylococcal or enterococcal infections of patients which have common drug resistance. 


\section{Material and method}

\subsection{MRSA isolates}

Thwenty-six isolates, which were isolated from intencive care unit (ICU) between September 2009-February 2010, were clinical isolates from ICU patients in Denizli Hospital. The isolates were identified as MRSA in hospital before obtaining. These isolates were obtained from tracheal aspirates, catheter tip, wounds, urine, blood, and effluxion, in a total of 26 strains were taken into account. Colonies were also checked by Gram-staining. Isolates were also identified by growth on Dnase test agar with methyl gren agar by DNase test. Table 1 shows the isolates and their origins.

\begin{tabular}{|c|c|c|c|}
\hline Code of Strains & Source & Code of Strains & Source \\
\hline MRSA 1 & tracheal aspirates & MRSA 14 & tracheal aspirates \\
\hline MRSA 2 & effluxion & MRSA 15 & tracheal aspirates \\
\hline MRSA 3 & tracheal aspirates & MRSA 16 & tracheal aspirates \\
\hline MRSA 4 & blood & MRSA 17 & tracheal aspirates \\
\hline MRSA 5 & blood & MRSA 18 & urine \\
\hline MRSA 6 & catheter tip & MRSA 19 & tracheal aspirates \\
\hline MRSA 7 & blood & MRSA 20 & blood \\
\hline MRSA 8 & blood & MRSA 21 & tracheal aspirates \\
\hline MRSA 9 & tracheal aspirates & MRSA 22 & catheter tip \\
\hline MRSA 10 & blood & MRSA 23 & blood \\
\hline MRSA 11 & urine & MRSA 24 & wound \\
\hline MRSA 12 & tracheal aspirates & MRSA 25 & blood \\
\hline MRSA 13 & tracheal aspirates & MRSA 26 & wound \\
\hline
\end{tabular}

Table shows MRSA samples obtained from 26 of patients, Denizli hospital

Table 1. MRSA strains and isolation resources

\subsection{Media}

Tryptic soy broth (TSB) medium (g/l:pepton from casein 17, pepton from soy meal 3, $\mathrm{D}(+)$ glucose 2.5, NACL Dipotassium hydrogen phosphate) was used for cultering MRSA 
strains at the study of antibiotic susceptibility. Tryptic soy agar (TSA) solid medium (g/l: pepton from casein 15.0; pepton from soymeal 5.0; Sodium chloride 5.0; agar-agar 15.0) was used for antibiogram tests. DNAase test agar with methyl green medium was used to determinate the DNAase activity. All of media were autoclaved at $121{ }^{\circ} \mathrm{C}^{\prime} \mathrm{de}$ for $15 \mathrm{~min}$. and stored at $4{ }^{\circ} \mathrm{C}$ until using.

\subsection{Antimicrobial susceptibilities}

To determinate multiple antibiotic resistan of MRSA trains, antibiotic susceptibilities were investigated by disc diffusion method. Susceptibility to methicillin by disc diffusion had allready determined by cefoxitin $(30 \mu \mathrm{g})$ discs before samples taking from hospital. The zone of inhibition was interpreted after $24 \mathrm{~h}$ of incubation at $35{ }^{\circ} \mathrm{C}$. Plates were read at 24 and $48 \mathrm{~h}$ of incubation at $37^{\circ} \mathrm{C}$. In addition to cefoxitin (FOX, $30 \mu \mathrm{g}$ ), the following antibiotics were tested: vancomycin (VA, $30 \mu \mathrm{g})$, tetracycline (TE, $30 \mu \mathrm{g})$, erythromycin (E, $15 \mu \mathrm{g}$ ), clindamycin (DA, $2 \mu \mathrm{g}$ ), rifampicin (RA, $5 \mathrm{mcg}$ ), linezolid (LZD, $30 \mu \mathrm{g}$ ),, sulfamethoxazole / trimethoprim (SXT, $25 \mathrm{mcg}$ ), penicillin-G (P, 10 unit), amikacin (AK, $30 \mathrm{mcg}$ ), seforoksimsodyum (CXM, $30 \mathrm{mcg})$, Novobiosin (NV, $5 \mu \mathrm{g})$, ampicillin (AM, $10 \mathrm{mcg}$ ) and gentamicin $(\mathrm{CN}, 10 \mathrm{mcg})$ antibiotics.

\subsection{Extraction of Whole Cell Proteins (WCPs)}

The method of Laemmli [34] was used by a little modification for electrophoresis. After overnight incubation at $37{ }^{\circ} \mathrm{C}$ for $24 \mathrm{~h}$. in $5 \mathrm{ml}$ of TSB (Merc) media, samples were centrifuged for $20 \mathrm{~min}$ at $6000 \mathrm{rpm}$. The pellets were washed three times with sterile distilled water and stirred after adding $25 \mu \mathrm{l}$ SDS sample buffer (0.06 M Tris, $2.5 \%$ glycerol, $0.5 \%$ SDS, $1.25 \% \beta$-mercaptoethanol and $0.001 \%$ bromophenol blue). The proteins were denatured in boiling water for $10 \mathrm{~min}$. Samples stayed in eppendorf tubes were uploaded to electrophoresis apparatus.

\section{SDS-PAGE}

Denatured whole cell proteins were analyzed by SDS-PAGE according to Laemmli. This method used $4 \%$ acrylamide stacking gel and $10 \%$ acrylamide separating gel. MBI Fermentas SM0661 kit was used as molecular weight standard in SDS-PAGE. Electrophoresis was performed with buffer system in a Biolab gel apparatus model V20-CDC. The gel was run at $150 \mathrm{~V}$ for $2 \mathrm{~h}$ at stacking gel, $200 \mathrm{~V}$ for $4 \mathrm{~h}$ at sperating gel until the bromophenol blue had reached the bottom. Gels were then stained with Coomassie Brilliant Blue $\mathrm{R}$ 250 (Sigma).

\subsection{Determination of DNase activity}

Following overnight incubation at $37{ }^{\circ} \mathrm{C}$ for $24 \mathrm{~h}$. in TSB (Merc) media, 26 of MRSA strains were inoculated a full loop of cells to petridishes where place DNase test agar with methyl 
green media and were applied the spot test. Inoculeted cells were incubated for overnight at $37{ }^{\circ} \mathrm{C}$ for $24 \mathrm{~h}$. After incubation, $1 \mathrm{~N}$ of $\mathrm{HCl}$ was dumped onto plates which grow MRSA colonies. It was checked whether achromatic color zone occur or not. The colonies occurring achromatic color zone were accepted as DNase positive strains, others were accepted DNase negative strains.

\section{Results}

\subsection{Antimicrobial susceptibilities}

Antimicrobial susceptibility testing was performed as recommended by the National Committee on Clinical Laboratory Standards [35,36]. MRSA samples that we used in our study were activated by culturing freshly at $37^{\circ} \mathrm{C}$ for $24 \mathrm{~h}$. two times. $100 \mu \mathrm{l}$ from these activared fresh culture samples were done smear cultivation to petridishes of TSA medium. Antibiotic discs were fixed up to surface of the media by using Disc diffusion method under steril conditions. The samples were incubated at $37^{\circ} \mathrm{C}$ for $24 \mathrm{~h}$. and the diameters of zone were measured.

In general, It was determinated that all of strains showed resistance against all of antibiotics. No zone of inhibition has been seen only against cefoxitin (FOX, $30 \mu \mathrm{g}$ ) antibiotic. It was observed that the zone did not occur except a few strains and strains were resistant against penicilin, amikacin (AK, $30 \mathrm{mcg}$ ), sulfamethoxazole / trimethoprim (SXT, $25 \mathrm{mcg}$ ), ampicillin (AM, $10 \mathrm{mcg}),(\mathrm{CN}, 10 \mathrm{mcg})$, erythromycin $(\mathrm{E}, 15 \mu \mathrm{g})$ and rifampicin (RA, $5 \mathrm{mcg}$ ) antibiotics. Beyond linezolid (LZD, $30 \mu \mathrm{g}$ ) which have started clinic using also in our country recently and used alternatively as an antimicrobial agent against glikopeptits in M-R strains, it was determinated that MRSA strains used in this study were resistant against this antibiotic. Even though it was detected that there was no resistance against vancomycin (VA, $30 \mu \mathrm{g})$ for MRSA infection in many studies, the sensitivity of vancomycin (VA, $30 \mu \mathrm{g}$ ) decreased significantly against MRSA strains in our study. Table 2 shows the results of antibiotic susceptibility.

\subsection{Determination of DNase activity}

Acording to the DNase tests, three of strains are DNase negative, the rest of 26 strains are DNase positive. Strains were $11.54 \%$ DNase negative and $88.46 \%$ DNase positive. Table 2 shows the results of DNase activity (Also, see figure 3).

\subsection{SDS-PAGE}

With regard to SDS PAGE analyzes whole cell proteins (WCPs) of MRSA strains showed the similar protein profile bands. Figure 4 and 5 show the band profiles obtained from WCPs (Also, see figure 4 ). 
http://dx.doi.org/10.5772/55457

\begin{tabular}{|c|c|c|c|c|c|c|c|c|c|c|c|c|c|c|c|}
\hline \multirow{2}{*}{$\begin{array}{l}\text { Code of } \\
\text { Strains }\end{array}$} & \multicolumn{14}{|c|}{ Antibiotics } & \multirow{2}{*}{$\begin{array}{c}\text { Dnaz } \\
\text { Activity }\end{array}$} \\
\hline & VA 30 & TE 30 & E 15 & DA 2 & RA 5 & LZD 30 & FOX 30 & SXT 25 & P 10 & AK 30 & CXM 30 & NV 5 & AM 10 & CN 10 & \\
\hline MRSA1 & $\mathrm{R}$ & $\mathrm{R}$ & $\mathrm{R}$ & $\mathrm{R}$ & $\mathrm{R}$ & $\mathrm{R}$ & $\mathrm{R}$ & $\mathrm{R}$ & $\mathrm{R}$ & $\mathrm{R}$ & $\mathrm{R}$ & $\mathrm{R}$ & $\mathrm{R}$ & $\mathrm{R}$ & Positive \\
\hline MRSA2 & $\mathrm{R}$ & $\mathrm{R}$ & $\mathrm{R}$ & $\mathrm{R}$ & $\mathrm{R}$ & $\mathrm{R}$ & $\mathrm{R}$ & $\mathrm{R}$ & $\mathrm{R}$ & $\mathrm{R}$ & $\mathrm{R}$ & $\mathrm{R}$ & $\mathrm{R}$ & $\mathrm{R}$ & Positive \\
\hline MRSA3 & $\mathrm{R}$ & $\mathrm{R}$ & $\mathrm{R}$ & $\mathrm{R}$ & $\mathrm{R}$ & $R$ & $\mathrm{R}$ & $\mathrm{R}$ & $\mathrm{R}$ & $\mathrm{R}$ & $\mathrm{R}$ & $\mathrm{R}$ & $\mathrm{R}$ & $\mathrm{R}$ & Positive \\
\hline MRSA4 & $\mathrm{R}$ & $\mathrm{R}$ & $\mathrm{R}$ & $\mathrm{R}$ & $\mathrm{R}$ & $\mathrm{R}$ & $\mathrm{R}$ & $\mathrm{R}$ & $\mathrm{R}$ & $\mathrm{R}$ & $\mathrm{R}$ & $\mathrm{R}$ & $R$ & $\mathrm{R}$ & Positive \\
\hline MRSA5 & $\mathrm{R}$ & $\mathrm{R}$ & $\mathrm{R}$ & $\mathrm{R}$ & $\mathrm{R}$ & $\mathrm{R}$ & $\mathrm{R}$ & $\mathrm{R}$ & $\mathrm{R}$ & $\mathrm{R}$ & $\mathrm{R}$ & $\mathrm{R}$ & $\mathrm{R}$ & $\mathrm{R}$ & Positive \\
\hline MRSA6 & $\mathrm{R}$ & $\mathrm{R}$ & $\mathrm{R}$ & $\mathrm{R}$ & $\mathrm{R}$ & $\mathrm{R}$ & $\mathrm{R}$ & $\mathrm{R}$ & $\mathrm{R}$ & $\mathrm{R}$ & $R$ & $\mathrm{R}$ & $\mathrm{R}$ & $\mathrm{R}$ & Positive \\
\hline MRSA7 & $\mathrm{R}$ & $\mathrm{R}$ & $\mathrm{R}$ & $\mathrm{R}$ & $R$ & $\mathrm{R}$ & $\mathrm{R}$ & $\mathrm{R}$ & $R$ & $\mathrm{R}$ & $\mathrm{R}$ & $\mathrm{R}$ & $\mathrm{R}$ & $\mathrm{R}$ & Positive \\
\hline MRSA8 & $\mathrm{R}$ & $\mathrm{R}$ & $\mathrm{R}$ & $\mathrm{R}$ & $\mathrm{R}$ & $\mathrm{R}$ & $\mathrm{R}$ & $\mathrm{R}$ & $\mathrm{R}$ & $\mathrm{R}$ & $\mathrm{R}$ & $\mathrm{R}$ & $\mathrm{R}$ & $\mathrm{R}$ & Positive \\
\hline MRSA9 & $\mathrm{R}$ & $\mathrm{R}$ & $\mathrm{R}$ & $\mathrm{R}$ & $\mathrm{R}$ & $\mathrm{R}$ & $\mathrm{R}$ & $\mathrm{R}$ & $\mathrm{R}$ & $\mathrm{R}$ & $\mathrm{R}$ & $\mathrm{R}$ & $\mathrm{R}$ & $\mathrm{R}$ & Positive \\
\hline MRSA10 & $\mathrm{R}$ & $\mathrm{R}$ & $\mathrm{R}$ & $\mathrm{R}$ & $\mathrm{R}$ & $\mathrm{R}$ & $\mathrm{R}$ & $\mathrm{R}$ & $\mathrm{R}$ & $\mathrm{R}$ & $\mathrm{R}$ & $\mathrm{R}$ & $\mathrm{R}$ & $\mathrm{R}$ & Positive \\
\hline MRSA11 & $\mathrm{R}$ & $\mathrm{R}$ & $\mathrm{R}$ & $\mathrm{R}$ & $\mathrm{R}$ & $\mathrm{R}$ & $\mathrm{R}$ & $\mathrm{R}$ & $\mathrm{R}$ & $\mathrm{R}$ & $\mathrm{R}$ & $\mathrm{R}$ & $R$ & $\mathrm{R}$ & Negative \\
\hline MRSA12 & $\mathrm{R}$ & $\mathrm{R}$ & $\mathrm{R}$ & $\mathrm{R}$ & $\mathrm{R}$ & $\mathrm{R}$ & $\mathrm{R}$ & $\mathrm{R}$ & $R$ & $\mathrm{R}$ & $\mathrm{R}$ & $\mathrm{R}$ & $\mathrm{R}$ & $\mathrm{R}$ & Positive \\
\hline MRSA13 & $\mathrm{R}$ & $\mathrm{R}$ & $R$ & $\mathrm{R}$ & $R$ & $\mathrm{R}$ & $R$ & $R$ & $R$ & $R$ & $R$ & $\mathrm{R}$ & $R$ & $\mathrm{R}$ & Positive \\
\hline MRSA14 & $\mathrm{R}$ & $\mathrm{R}$ & $\mathrm{R}$ & $\mathrm{R}$ & $\mathrm{R}$ & $\mathrm{R}$ & $\mathrm{R}$ & $\mathrm{R}$ & $\mathrm{R}$ & $\mathrm{R}$ & $\mathrm{R}$ & $\mathrm{R}$ & $\mathrm{R}$ & $\mathrm{R}$ & Positive \\
\hline MRSA15 & $\mathrm{R}$ & $\mathrm{R}$ & $R$ & $\mathrm{R}$ & $R$ & $\mathrm{R}$ & $\mathrm{R}$ & $\mathrm{R}$ & $R$ & $\mathrm{R}$ & $\mathrm{R}$ & $\mathrm{R}$ & $\mathrm{R}$ & $\mathrm{R}$ & Negative \\
\hline MRSA16 & $\mathrm{R}$ & $\mathrm{R}$ & $\mathrm{R}$ & $\mathrm{R}$ & $\mathrm{R}$ & $\mathrm{R}$ & $\mathrm{R}$ & $\mathrm{R}$ & $\mathrm{R}$ & $\mathrm{R}$ & $\mathrm{R}$ & $\mathrm{R}$ & $\mathrm{R}$ & $\mathrm{R}$ & Positive \\
\hline MRSA17 & $\mathrm{R}$ & $\mathrm{R}$ & $\mathrm{R}$ & $\mathrm{R}$ & $R$ & $R$ & $\mathrm{R}$ & $\mathrm{R}$ & $\mathrm{R}$ & $\mathrm{R}$ & $\mathrm{R}$ & $\mathrm{R}$ & $\mathrm{R}$ & $\mathrm{R}$ & Positive \\
\hline MRSA18 & $\mathrm{R}$ & $\mathrm{R}$ & $\mathrm{R}$ & $\mathrm{R}$ & & $\mathrm{R}$ & $\mathrm{R}$ & MS & $\mathrm{R}$ & $\mathrm{R}$ & $\mathrm{R}$ & $\mathrm{R}$ & $R$ & $\mathrm{R}$ & Negative \\
\hline MRSA19 & $\mathrm{R}$ & $\mathrm{R}$ & $\mathrm{R}$ & $\mathrm{R}$ & $\mathrm{R}$ & $\mathrm{R}$ & $\mathrm{R}$ & $\mathrm{R}$ & $R$ & $\mathrm{R}$ & $\mathrm{R}$ & $\mathrm{R}$ & $\mathrm{R}$ & $\mathrm{R}$ & Positive \\
\hline MRSA20 & $\mathrm{R}$ & $\mathrm{R}$ & $\mathrm{R}$ & $\mathrm{R}$ & $R$ & $\mathrm{R}$ & $R$ & $\mathrm{R}$ & $\mathrm{R}$ & $\mathrm{R}$ & $R$ & $\mathrm{R}$ & $\mathrm{R}$ & $\mathrm{R}$ & Positive \\
\hline MRSA21 & $\mathrm{R}$ & $\mathrm{R}$ & $\mathrm{R}$ & $\mathrm{R}$ & $R$ & $\mathrm{R}$ & $\mathrm{R}$ & $\mathrm{R}$ & $R$ & $\mathrm{R}$ & $\mathrm{R}$ & $\mathrm{R}$ & $\mathrm{R}$ & $\mathrm{R}$ & Positive \\
\hline MRSA22 & $\mathrm{R}$ & $\mathrm{R}$ & $\mathrm{R}$ & $\mathrm{R}$ & $\mathrm{R}$ & $\mathrm{R}$ & $\mathrm{R}$ & $\mathrm{R}$ & $R$ & $\mathrm{R}$ & $\mathrm{R}$ & $\mathrm{R}$ & $\mathrm{R}$ & $\mathrm{R}$ & Positive \\
\hline MRSA23 & $\mathrm{R}$ & $\mathrm{R}$ & $\mathrm{R}$ & $\mathrm{R}$ & $\mathrm{R}$ & $\mathrm{R}$ & $\mathrm{R}$ & $\mathrm{R}$ & $\mathrm{R}$ & $\mathrm{R}$ & $\mathrm{R}$ & $\mathrm{R}$ & $\mathrm{R}$ & $\mathrm{R}$ & Positive \\
\hline MRSA24 & $\mathrm{R}$ & $\mathrm{R}$ & $\mathrm{R}$ & $\mathrm{R}$ & $\mathrm{R}$ & $\mathrm{R}$ & $\mathrm{R}$ & $\mathrm{R}$ & $\mathrm{R}$ & $\mathrm{R}$ & $\mathrm{R}$ & $\mathrm{R}$ & $\mathrm{R}$ & $\mathrm{R}$ & Positive \\
\hline MRSA25 & $\mathrm{R}$ & $\mathrm{R}$ & $\mathrm{R}$ & $\mathrm{R}$ & $\mathrm{R}$ & $\mathrm{R}$ & $\mathrm{R}$ & $\mathrm{R}$ & $\mathrm{R}$ & $\mathrm{R}$ & $\mathrm{R}$ & $\mathrm{R}$ & $\mathrm{R}$ & $\mathrm{R}$ & Positive \\
\hline MRSA26 & $\mathrm{R}$ & $\mathrm{R}$ & $\mathrm{R}$ & $\mathrm{R}$ & $\mathrm{R}$ & $\mathrm{R}$ & $\mathrm{R}$ & $\mathrm{R}$ & $\mathrm{R}$ & $\mathrm{R}$ & $\mathrm{R}$ & $\mathrm{R}$ & $\mathrm{R}$ & $\mathrm{R}$ & Positive \\
\hline
\end{tabular}

R; Resistant, MS; Medium Sensetive, S; Sensetive (No sensetive strains in our study)

Table 2. Antibiotics susceptibility and DNase activity of MRSA strains

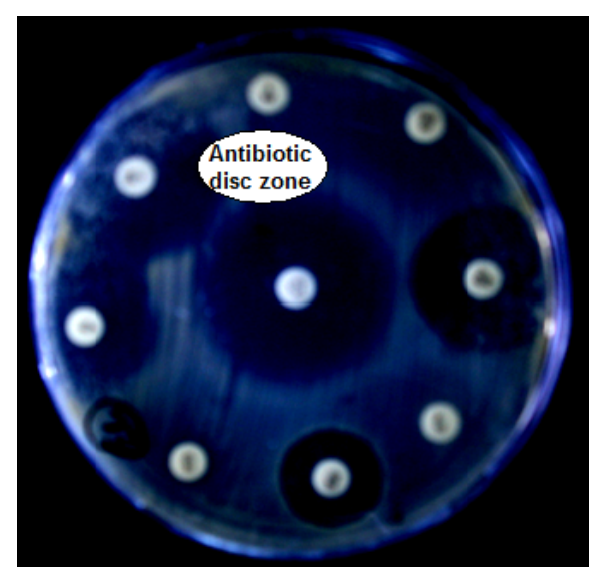

Figure 2. MRSA-24 antibiotic inhibition zones 


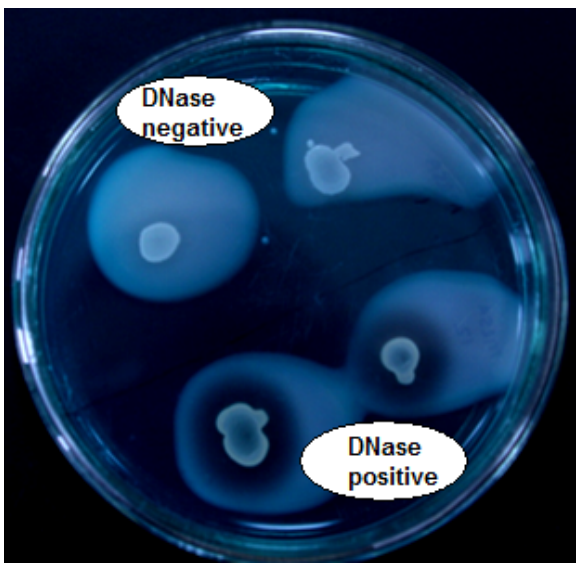

Figure 3. DNase activity test

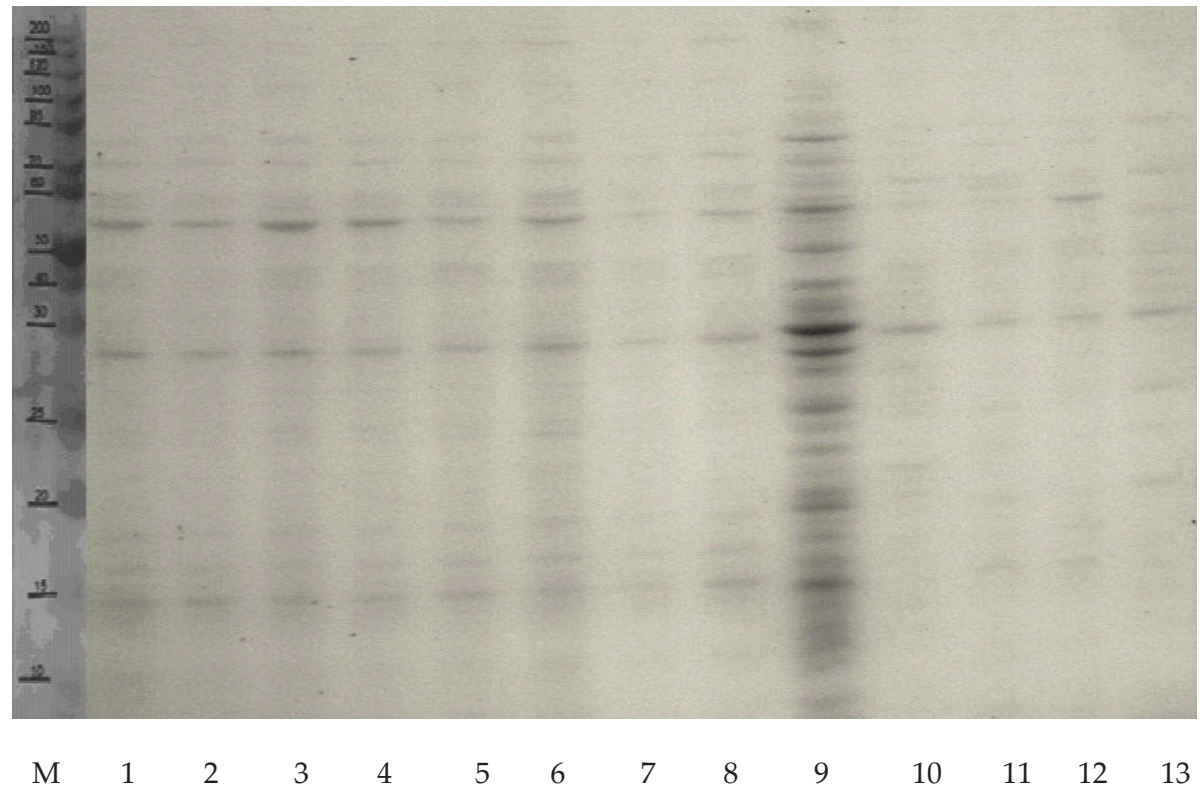

Figure 4. Whole cell protein profiles of MRSA strains by SDS-PAGE. Line 1-13: MRSA strains from ICU; Line M: Molecular weight standard in $\mathrm{kD}$. 


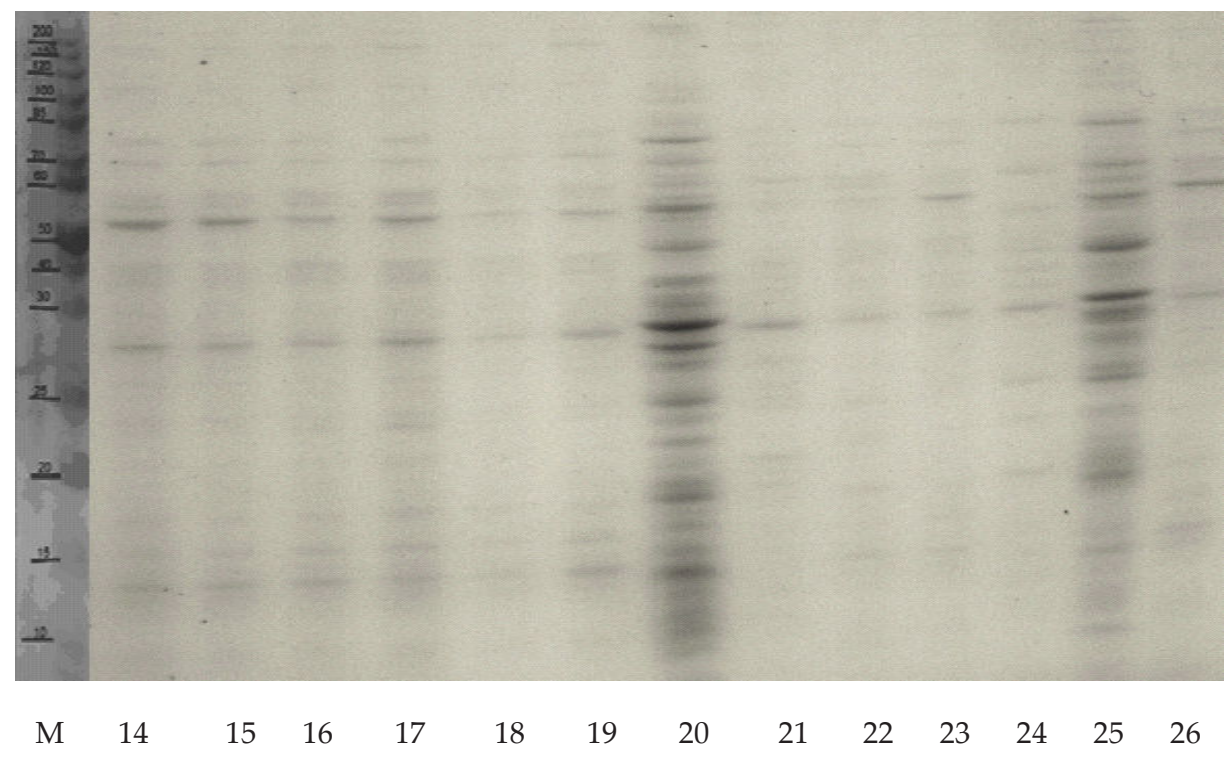

Figure 5. Whole cell protein profiles of MRSA strains by SDS-PAGE. Line 14-26: MRSA strains from ICU; Line M: Molecular weight standard in $\mathrm{kD}$.

\section{Discussion}

Most of methods have been applied to determinate the MRSA strains. In the present study, SDS- PAGE was used for typing MRSA strains obtained from the various wards of patients in ICU. By SDS-PAGE (WCPs), all of the 26 MRSA strains, of which 11 from tracheal aspirat, 8 from blood, 2 from urine, 2 from wounds, 2 from catheter tip and the other one from effluxion were compared proteins profiles each other. Results of this study in MRSA strains by SDSPAGE and previous studies obviusly indicate that valuable epidemiological informations can be demonstrated with electrophoretic methods. It is reported that WCPs can not be used because of the high similarities between their band patterns examined in the differentiation of MRSA strains [37]. In order to overcome this problem, it is necessary to make SDS-PAGE with the use of FPs and by N-PAGE using WCPs. Also this problem can dissolve when $5-7.5 \%$ gel concentration uses in SDS-PAGE as opposed to $10 \%$ gel concentration [37]. In this study we applied only SDS-PAGE with use WCPs because of inadequate time of study term.

By using various antibiotic discs, in study of antibiotic susceptibility, generally all of the MRSA strains showed multiple drug resistance. The high level morbidity and mortality of MRSA infections has caused to trace the prevalence of multiple antibiotic resistant staphylococci mainly on the brink of MRSA. In Turkey between 1996-1999, the average of resistant against methicillin was detected $47,5 \%$. Vancomicin being glycopeptit antibiotic 
is very important because of methicillin resistant in staphylococcus's. Until now the resistance of glycopeptit was no informed in many studies which have done in our country $[9,38]$. In our study, we investigated that none of MRSA strains wree resistance against Vancomycin. Susceptibilities of antibiotic groups such as fucidic acid, sulfamethoxazole / trimethoprim, clindamycin, erithromycin, and quinolone have come into prominence because of alternativ treatment options of those antibiotics without glycopeptit antibiotics in patients having light and middle infections of MRSA and remediabled on erect pozition. SXT is an other antibiotic not to be $\beta$-lactam which uses in resistant staphilococcus's. Even though, susceptibility of SXT for MRSA strains was $81 \%$ in our study, it was $91 \%$ in study of Sengoz [19]. Also we found that rate of resistant strains for eritromycin antibiotic was $73 \%$. In one study done in laboratory of clinic microbiology, Haydar Paşa Hospital, this rate for eritromycin was found $71 \%$. In general it was considered that eritromycin antibiotic is not to be alternativ antibiotic option for treatment in MRSA's. Clindamycin is an alternativ antibiotic which can use in infections of staphylococcus. We found that resistant of clindamycin to MRSA strain was $23 \%$ in present study. A few studies which had been done in Turkey ; in study of Gonluugur resistant of clindamycin was 39\%, in study of Dogan it was 54\% [10,39].Linezolid is the first member of antibiotics which are from oksazolidinon group. Linezolids do not show the cross resistant with other antibiotics due to different effect mechanism of those antibiotics. Also, to resistant evolve is power against in vitro linezolid. Resistant evolving occurs typicaly with single nucleotid chancing in genes which encode the 23 S rRNA. In present study, susceptibility of linezolid was found $100 \%$. It was found that linezolid antibiotic was effectiv and safe in $70 \%$ of facts with S.aureus infection which is not respondet or tolerant [40]. Unfortunately in our country, there is limeted number of study associated with Linezolid. This rate of resistant was $92 \%$ against gentamicin in our study.

In this study, we investigated antibiotic susceptibilities, DNase activity and protein profiles by SDS-PAGE of MRSA strains. It was determinate that MRSA strains were resistant against all of antibiotics. A significant decrease in Vancomicin susceptibility is particularly notable. Moreover, the strains were $11.54 \%$ DNase negative and $88.46 \%$ DNase positive. Also strains showed similarities of band pattern for protein profiles by SDS-PAGE. Studies of Sacilik et al. (1999) and Van Belkum et al. (1997) [41] supported that dissemination of MRSA strains in Turkish hospitals probably originated from the same clone. In order to demostrate such informations and to understand clearly, it is nessesary to make more molecular genetic analyzes and studies in many zones of Turkey.

\section{Acknowledgements}

We acknowledge Nilüfer AYDINLIK for her valuable assistance. We are also grateful personel of Denizli Hospital for MRSA samples. 


\section{Author details}

Göksel Doğan*, Gülümser Acar Doğanlı, Yasemin Gürsoy and Nazime Mercan Doğan

*Address all correspondence to: gksldogan@hotmail.com

Pamukkale University, Faculty of Arts and Sciences, Department of Biology, Denizli, Turkey

\section{References}

[1] Goss, C.H., Muhlebach, M.S., 2011. Staphylococcus aureus and MRSA in cystic fibrosis. Journal of Cystic Fibrosis 10; 298-306

[2] Azaez Akande, O., 2010. Global trend of methicillin-resistant Staphlococcus aureus and emergingchallenges for control. Afr. J. Cln. Exper. Microbiol 11(3): 150-158.

[3] Rello, J., Diaz, E. 2003. Pneumonia in the intensive care unit. Crt. Care Med.; 31: 2544 $-2551$.

[4] Graffunder. E.M., Venezia, R.A., 2002.Risk factors associated with nosocomial methicillin resistant Staphylococcus aureus (MRSA) infection including previous use of antimicrobials. J. Antimicrob. Chemother.; 49:999 - 1005.

[5] Gottileb, G.S., Fowler, V.G. Jr., Kong, L.K. et al. 2000. Staphylococcus aureus bacteremia in the surgical patients: a prospective analysis of 73 postoperrative patients who developed Staphylococcus aureus bacteremia at a tertiary care facility. J. Am. CoIl. Surg.; 190:50 - 57.

[6] Mylotte, J.M., Tayara, A. 2000. Staphylococcus aureus bacteremia: predictors of 30 - day mortality in a large cohort. Clin. Infect. Dis.; 31: 1170 - 1174.

[7] Watkins, R.R., David, M.Z., Salata, R.A., 2012. Current concepts on the virulence mechanisms of meticillin-resistant Staphylococcus aureus. Journal of Medical Microbiology Papers in Press. Published June 28, 2012 as doi:10.1099/jmm.0.043513-0.

[8] Chang, S., Sievert, D.M., Hageman, J.C., 2003. Infection with vancomycin-resistant Staphylococcus aureus containing the vanA resistance gene. N Engl J Med,; 348:13421347

[9] Chang, F.Y., MacDonald, B.B., Peacock, J.E., Jr, 2003. A prospective multicenter study of Staphylococcus aureus bacteremia: incidence of endocarditis, risk factors for mortality, and clinical impact of methicillin resistance. Medicine ; 82:322-332. 
[10] Cosgrove, S.E., Qi Y, Kaye K.S., 2005. The impact of methicillin resistance in Staphylococcus aureus bacteremia on patient outcomes: mortality, length of stay, and hospital charges. Infect Control Hosp Epidemiol; 26:166-174.

[11] Chambers, H.F., 1988. Methicillin-resistant staphylococci. Clin Microbiol Rev; 1:173-86.

[12] Moran, GJ., Amii, R.N., Abrahamian, F.M., Talan, D.A 2005. Methicillin resistant Staphylococcus aureus in community - acquired skin infections. Emerg. Infect. Dis; 11 (11): 928 - 930.

[13] Chambers, H.F., 1997. Methicillin resistance in staphylococci: molecular and biochemical basis and clinical implications. American society for clinical microbiology. 4 ; 781-91.

[14] http://sci.kufauniv.com/teaching/hazim/bacteria/strept.doc.

[15] Koneman, E.W., Allen, S.D., William, M.J., Schereckenberger, P.C., Winn, W.C., 2006. Gram-positive cocci, Part I: Staphylococci and related gram-positive cocci. Winn WC Jr et al (editors). Color atlas and textbook of diagnostic microbiology, 6th ed. Lippincott Williams and Wilkins; 623-71.

[16] Jorgensen, J.H., 1997. Laboratory issues in the detection and reporting of antibacterial resistance. Infect Dis Clin North Am; 11:785-802.

[17] Hartman, B.J., Tomasz, A., 1986. Expression of methicillin resistance in heterogeneous strains of Staphylococcus aureus. Antimicrob Agents and Chemother; 29:85-92.

[18] Kuwahara-Arai, K., Kondo, N., Hori, S., Tateda-suzuki, E., Hiramatsu, K,. 1996. Suppression of methicillin resistance in a mecA containing pre-methicilin-resistant Staphylococcus aureus strain is caused by the mecI mediated repression of PBP 2' production. Antimicrob Agents Chemother; 40:2680-5.

[19] Gulay, Z., 1999. Gülay Z. Antimikrobiyal ilaçlara direnç. Mutlu G, İmir T, Cengiz T, Ustaçelebi Ş, Tümbay E, Mete Ö (eds). Temel ve Klinik Mikrobiyoloji. Ankara: Güneş Kitabevi, 1999:91-108.

[20] Maranan, M.C., Moreira, B., Boyle-Vavra, S., Daum, R.S., 1997. Antimicrobial resistance in staphylococci. Infect Dis Clin North Am; 11:813-49.

[21] Hackbarth, C.J., Chambers, H.F., 1993. blaI and blaR1 regulate $\beta$-lactamase and PBP 2a production in methicillin resistant Staphylococcus aureus. Antimicrob Agents Chemother; 37:1144-9.

[22] Brooks, G.F., Carroll, K.C., Butel, J.S., Morse, S., 2007. The Staphylococci. In: Jawetz, Melnick and Adelberg's medical microbiology. 24th ed. New York; McGraw-Hill.

[23] Bronner, S., Monteil, H., Prévost. G,. 2004. Regulation of virulence determinants in Staphylococcus aureus: Complexity and applications. FEMS Microbiol Rev; 28:183. 
[24] Mulligan, M.E., Murray-Leisure, K.A., Standiford, H.C., 1993. Methicillin- resistant Staphylococcus aureus: a consessus review of the microbiology, pathogenesis and epidemiology with implications for prevention and management. Am J Med; 94:313-28.

[25] Thorsherry, C., 1984. Methicillin-resistant (heteroresistant) Staphylococci Antimicrobic Newsletter $1 ; 6$.

[26] Franklin, D.L., 1998. Staphylococcus aureus infections. N EnglJ Med,; 339:520-32.

[27] Novick RP, Schelievert P, Ruzin A. 2001. Pathogenicity and resistance islands of staphylococci. Microbes and Infect;3:585.

[28] Boye, K., Bartels, M.D., Andersen, I.S., Møller, J.A., Westh, H.,2007. A new multiplex PCR for easy screening of methicillin-resistantStaphylococcus aureus SCCmec types IV. Clinical Microbiology and Infection Volume 13, Issue 7, pages 725-727.

[29] Donnio, P.Y., Preney, L., Gautier-Lerestif, A.L., Avril, J.L., Lafforgue, N., 2004. Changes in staphylococcal cassette chromosome type and antibiotic resistance profile in methicillin-resistant Staphylococcus aureus isolates from a French hospital over an 11 year period. Journal of Antimicrobial Chemotherapy (2004) 53, 808-813.

[30] Klevens, R.M. et al., 2007. Invasive methicillin-resistant Staphylococcus aureus infections in the United States, J. Am. Med. Assoc. 298, 1763-1771.

[31] Kirca, Catar, F., 2008. Staphylococcus aureus suslarinda metisilin direnci tanisinda kullanilan bazi fenotipik yöntemlerin karsilastirilmasi. Uzmanlık Tezi, Gazi Universitesi, Tip Fakultesi, Tibbi Mikrobiyoloji Anabilim Dali, Ankara, Turkiye.

[32] Murray, P.R., Rosenthal, K.S., Kobayashi, G.S., Pfaller M.A., 2002. Staphylococcus and related organisms. Mosby Inc. St. Louis: 202-216.

[33] www.havasteril.com/images/xx/uygulamalar.htm

[34] Laemmli, U.K., 1970. Cleavage of structural proteins during the assembly of head of bacteriophage T4. Nature (London), 227: 680-85.

[35] National Committee for Clinical Laboratory Standards, 2000a. Methods for dilution antimicrobial susceptibility test for bacteria that grow aerobically, 5th ed. Approved standard M7-A5. National Committee for Clinical Laboratory Standards, Wayne, Pa.

[36] National Committee for Clinical Laboratory Standards, 2000b. Performance standard for antimicrobial susceptibility testing. Document M100-S10. National Committee for Clinical Laboratory Standards, Wayne, Pa.

[37] Sacilik, S.C., Osmanoglu, O., Palbiyikoglu, U., Bengisun, J.S., Cokmus, C., 2000. Analysis of Methicillin Resistant Staphylococcus aureus Isolates by Polyacrylamide Gel Electrophoresis in an Intensive Care Unit of Ibni-Sina Hospital. Turk J Med Sci. 30 367-371. 
[38] Pa, W., 1997. National Committee for Clinical Laboratory Standarts. Performance standarts for antimicrobial disc susceptibility tests. Approved standart M2-A5, National Committee for Clinical Laboratory Standarts, 1997.

[39] Ridenour GA, Wong ES, Call MA, 2006. Duration of colonization with methicillin resistantStaphylococcus aureus among patients in the intensive care unit: implications for intervention. Infect Control Hosp Epidemiol,; 27:271-278.

[40] Doganay M., 1998. Nozokomiyal sepsis: önemi ve tanımlar, Hastane İnfeksiyon Dergisi; 2(4):179-81.

[41] Van Belkum, A., Van Leeuwen, W., Werkooyen R., Sacilik, S.C., Cokmus, C., Verbrugh H., 1997. Dissemination of a single clone of methicillin-resistant Staphylococcus aureus among Turkish hospitals. J Clin Microbiol, 35: 978-81, 